Journal of

Plant Science \&

Molecular Breeding

\title{
First genetic linkage map of chilling injury susceptibility in peach (Prunus persica (L.) Batsch) fruit with SSR and SNP markers
}

\author{
Arun Prabhu Dhanapal ${ }^{1,2 *}$, Pedro J Martínez-García ${ }^{1}$, Thomas M Gradziel ${ }^{1}$ and Carlos H Crisosto ${ }^{1}$ \\ Correspondence: dhanapala@missouri.edu \\ 'Plant Sciences Department, University of California Davis, One Shields Ave, Davis CA 95616, USA. \\ Present address: ${ }^{2}$ Division of Plant Sciences, University of Missouri, Columbia, USA.
}

\begin{abstract}
Peach and nectarine (Prunus persica L) are highly perishable; they ripen and deteriorate quickly at ambient temperature. Storage at low temperature $\left(0-5^{\circ} \mathrm{C}\right)$ is a common strategy used to slow the ripening processes and extending shelf life. However, if susceptible varieties are held too long at a low temperature, they will not ripen properly and will develop chilling injury (CI) symptoms like mealiness, flesh browning, and flesh bleeding. Understanding the genetic control of these traits to produce CI resistant cultivars will greatly benefit producers, shippers and consumers. Mapping approach for a set of 40 candidate genes (CGs) obtained after a transcriptomic analysis of peach between high tolerant and sensitivity to CI were used, to identify CI controlling genes in Pop-DG progeny population and CI-susceptible (hermoza) and chilling injury-resistant (oded) peaches. A set of 142 CGs from detailed transcriptomic analysis of two different peach cultivars studied previously and additional 10 CGs nominated from published works and review articles of physiology and transcriptomic study of peach fruit subjected to CI were localized in this study. In present study 12 CGs have been mapped on Pop-DG population with 8 SSR and 26 SNP markers.
\end{abstract}

Keywords: Chilling injury (CI), mapping, candidate genes (CGs), SNP and SSR

\section{Background}

Chilling injury $(\mathrm{Cl})$ is the collective term for various disorders that occur during prolonged cold storage and/or after subsequent ripening of stone fruit. Major symptoms of $\mathrm{Cl}$ include mealiness, flesh browning and red pigmentation (bleeding). Eventhough numerous biochemical and molecular studies identified several factors which may be important in the development of the symptoms, results are often contradictory and therefore we are still lacking complete understanding of the molecular basis for $\mathrm{Cl}$. Our present study proposed 12 candidate genes mapped in Pop-DG with SSR and SNP markers along with significant SNP markers for QTLs controlling $\mathrm{Cl}$. The elucidation of the inheritance mechanism of the chilling injury will provide a longterm solution of this problem and enable the breeding of new Cl-tolerant cultivars. The application of MAS will enable the selection of those $\mathrm{Cl}$-tolerant cultivars, diminishing the global peach industry losses due to this postharvest disorder.

\section{Introduction}

Peach tree (Prunus persica) is a species of Prunus, a genus that also includes nectarine, plum, apricot, cherry, and almond belonging to the subfamily Prunoideae of the family Rosaceae. It is considered one of the genetically most well characterized species in the Rosaceae, and it has distinct advantages that make it suitable as a model genome species for Prunus as well as for other species in the Rosaceae $[1,2]$. Peach is a diploid with $n=8$ and has a comparatively small genome currently estimated to be $\sim 220-230 \mathrm{Mbp}$ based upon the peach v1.0 assembly. Peach has a relatively short juvenility period of 2-3 years compared to most other fruit tree species that require 6-10 years. One of the key aspects of fruit ripening is softening and texture of the fruit. Peaches are highly perishable; they ripen and deteriorate quickly at ambient temperature [3]. Therefore, low temperature storage $\left(0-5^{\circ} \mathrm{C}\right)$ is used to slow the ripening processes as well as decay development during storage and/or shipment

(c) 2012 Dhanapal et al; licensee Herbert Publications Ltd. This is an open access article distributed under the terms of Creative Commons Attribution License (http://creativecommons.org/licenses/by/3.0),This permits unrestricted use, distribution, and reproduction in any medium, provided the original work is properly cited. 
$[3,4]$. These temperatures inhibit fruit ripening, thereby extending fruit postharvest life. If susceptible varieties of peach, nectarine, and other stone fruit such as plum and apricot are held too long at a low temperature they will not ripen properly when rewarmed and will develop chilling injury $(\mathrm{Cl}) . \mathrm{Cl}$ is the collective term for various disorders that occur during prolonged cold storage and/or after subsequent ripening of stone fruit. Major symptoms of $\mathrm{Cl}$ include mealiness, flesh browning and flesh bleeding. So peaches that are subjected to long periods of cold storage can develop chilling injury symptoms which reduce the postharvest quality of these fruits. The manifestations of $\mathrm{Cl}$ in peaches and nectarines include defective cell wall disassembly and development of a dry, woolly rather than soft, juicy texture [3]. Cl acts as main limiting factor in the shipping of some stone fruits and results in significant economic losses, limiting long distance transport, and affecting peach consumption with frequent complaint by consumers $[4,5]$.

Even though numerous biochemical studies have resulted in the identification of factors which may be important in the development of the symptoms $[3,6,7,8]$, results are often contradictory, and therefore, we are still lacking complete understanding of the molecular basis for mealiness. Some studies claim that mealiness is characterized by loss of juiciness has been associated with abnormal cell wall disassembly during ripening $[3,7,9,10]$. Normal peach fruit ripening involves a series of cell wall modifications and increased transcription of genes encoding proteins and enzymes associated with the functionality of the endomembrane system $[10,11]$. There are many enzymes associated with the determination of softening and texture, and several of these enzymes are encoded by multi-gene families [12]. Candidate genes are genes of known biological action involved with the development or physiology of the trait. CGs is of known or presumed function that could correspond to QTLs. These genes may be structural genes or genes in a regulatory or biochemical pathway affecting trait expression. Correlation between the trait understudy and allelic polymorphism at the candidate gene is a strong argument in favour of the candidate gene [13].

Transcriptomic analysis to study different $\mathrm{Cl}$ symptoms and associating the genes with each specific symptom is getting more popular. Fruit tissue obtained from two full-sib progeny individuals of Pop-DG with contrasting susceptibility to $\mathrm{Cl}$ and being subjected to various cold storage durations and ripening regimes were used to develop the ChillPeach EST collection, a specialized database (ChillPeach) to target genes expressed during $\mathrm{Cl}$ development. Genes controlling chilling injury differentially expressed between juicy and woolly fruit were found. In woolly fruit, commonly stress-induced genes, ripening related genes and genes involved in amino acid transport were up-regulated, while HSPs (Heat shock protein) genes were down-regulated, including genes putatively involved in intracellular trafficking and cell wall metabolism that were repressed in woolly fruit $[14,10]$. A study on peach, found differential expression of genes associated with plastids, mitochondria, endoplasmic membrane and ribosomes when comparing woolly and juicy fruit [15]. There is also some evidence that higher linolenic acid (C18:3) and membrane lipid unsaturation are beneficial for maintaining membrane fluidity, leading to an enhanced tolerance of peach fruit to low temperature [16]. Recent study found that heat shock and cold acclimation treatments induced chilling tolerance of plum fruit, which enhanced the expression of Ps-CII sHSP1 of fruit during subsequent low temperature storage [17].

To understand the genetic control of $\mathrm{Cl}$ and their molecular basis of sensitivity or tolerance to $\mathrm{Cl}$, a peach linkage map and a candidate gene approach based on current physiological information have been used $[14,18,19,20]$. In our previous study one major quantitative trait locus (QTL) and a few minor QTLs have been localized for mealiness, browning and bleeding using the Pop-DG map [19]. A gene encoding a cell wall modifying enzyme, endopolygalacturonase (endoPG) co-localized with the major QTL affecting mealiness [18,21]. Another gene in the anthocyanin biosynthesis pathway, leucoanthocyanidin dioxygenase (PpLDOX), mapped to the same genomic region where the major QTL controlling browning was identified [20]. The application of next generation sequencing technologies and bioinformatic scripts to generate high frequency SNPs distributed throughout the peach genome for use in genome mapping and phenotype selection and development of high density genetic linkage maps using SNP markers were constructed for two breeding populations, Pop-DF ('Dr. Davis' x 'F8, 1-42') with 117 progeny and Pop-DG ('Dr. Davis' $x$ 'Georgia Belle') with 64 progeny have been developed [22]. Transcriptomic analyses of two peach cultivars namely Oded and Hermoza, which differ in their resistance to chilling injury, were examined after two weeks of cold storage at $5^{\circ} \mathrm{C}$ by using ChillPeach cDNA microarray platform and identified 102 CGs proposed to be involved in $\mathrm{Cl}$ [23].

A combination of new genomic tools: a Chillpeach microarray $[14,23]$ and the Pop DG ('Dr. Davis' $x$ 'Georgia Belle') peach population [20] segregating for $\mathrm{Cl}$, in a bulk segregant gene expression analysis approach to investigate the changes in the peach fruit transcriptome and to reveal the genes underlying differential response to cold storage of sensitive and tolerant peach fruit. The results of the study proposed potential candidate genes involved in $\mathrm{Cl}$. Among the possible strategies used to identify genes in general, the "Candidate Gene" (CGs) approach to genetic mapping and QTL analysis still appears to be the simplest one for Prunus. The purpose of this study was to map potential candidate genes and to propose mapped CGs of Pop- DG as potential marker for $\mathrm{Cl}$ (Mealiness, flesh bleeding and fresh browning) and for use in marker assisted selection. In addition to the present objective of this study 102 CGs 
identified [23] have been localized in scaffolds of peach genome with at least one SNP flanking marker based on physical position.

\section{Materials and methods Plant materials}

Pop-DG' a peach intraspecific cross between 'Dr. Davis' (female parent) and 'Georgia Belle' (pollen parent) was used in this study. 'Dr.Davis' is a modern canning peach cultivar and 'Georgia Belle' is a century-old fresh market peach cultivar which contrasts for many fruit quality and other chilling injury related traits (Table 3). 'Pop-DG' was created and managed at Kearney Agricultural Center (Parlier, CA, USA). This orchard was established in 1998 containing 51 verified hybrids. Each progeny genotype was represented by two trees in the orchard; the leaves were collected from parents and 51 Pop-DG populations, any one of the orchard tree in April 2010 and frozen in liquid nitrogen and stored at $-80^{\circ} \mathrm{C}$ until used.

\section{DNA extraction}

DNA was extracted from leaves of 'Dr. Davis', 'Georgia Belle', and their progeny population. The plant tissue consisted of 2-6 expanding leaves of three $\mathrm{cm}$ length or less. Fresh leaf tissue of $\sim 5 \mathrm{~g}$ was ground into fine powder using liquid nitrogen. Ten $\mathrm{ml}$ of CTAB buffer $[100 \mathrm{ml}$ of $1 \mathrm{M}$ Tris $\mathrm{HCl}$ $\mathrm{pH} 8.0,280 \mathrm{ml}$ of $5 \mathrm{M} \mathrm{NaCl}, 40 \mathrm{ml}$ of $0.5 \mathrm{M}$ EDTA and 20 $\mathrm{g}$ of CTAB (cetyltrimethyl ammonium bromide) with total volume to $1 \mathrm{~L}$ with $\mathrm{ddH}_{2} \mathrm{O}$ ] was taken in $50 \mathrm{ml}$ falcone tube. Ground samples were put into buffer and $20 \mu$ of 2-mercaptoethanol was added and mixed well. This setup was left in water bath at $60^{\circ} \mathrm{C}$ for 30 minutes. Samples were taken and left outside to cool for 10 minutes before chlofoform-Isoamyl alcohol (24:1) was added until $30 \mathrm{ml}$ of the $50 \mathrm{ml}$ falcone tube and tilted well until the layer/ phases mixed well ( 2 to 5 times for five to 10 minutes). Tubes were taken to centrifuge for 30 minutes at 4000 rpm and were taken out carefully without disturbing the layers (two separate layers). Pasteur-pipette was used to obtain the upper phase to one new labeled falcone tube. Ice-cold Isopropanol $\left(-20^{\circ} \mathrm{C}\right)$ was added until $45 \mathrm{ml}$ of the $50 \mathrm{ml}$ falcone tube and mixed gently, the supernatant was discarded without disturbing the loose pellet-DNA. Twenty $\mathrm{ml}$ of wash-buffer $(30 \mathrm{ml}$ of $3 \mathrm{M}$ sodium acetate and $970 \mathrm{ml}$ of $100 \%$ ethanol) was added and mixed gently. This step was repeated 2-3 times until the DNA pellet was very clean. Final wash was made with $70 \%$ ethanol and let it dry until ethanol was completely evaporated. About 2-3 ml of 1 X TE was added to each falcone tubes.

\section{Candidate Gene selection for Pop-DG}

Fruit mesocarp samples of individual from the progeny peach trees of the Pop-DG mapping population were used. Genotypes selected represent siblings with extremes of susceptibility (one resistant $\mathrm{T}$, one susceptible $\mathrm{S}$ ) to mealiness and internal browning in Pop-DG. The $\mathrm{Cl}$ phenotype of the different genotypes was evaluated and confirmed similar to our previous study [14]. Fruit from the different genotypes were forced-air cooled at $0-2^{\circ} \mathrm{C}$ within $6 \mathrm{~h}$ of harvest and then stored at $5^{\circ} \mathrm{C}$ with $90 \%$ relative humidity. At 1, 2 and 3 weeks after cold storage (with or without shelf life), observations were made on the mesocarp for mealiness and browning and after this fruit were cut in halves through the suture plane.

Samples representing each at least 6 fruit from each of the genotypes with different treatments during harvesting, cold storage and ripening were bulked as described [14], and immediately frozen in liquid nitrogen before storing at $-80^{\circ} \mathrm{C}$ until used. The samples were later used for RNA extraction for gene expression studies and select potential candidate genes as described [23]. The genes selected from above microarray analysis were subjected to validation with 96.96 dynamic arrays results over the same pools of susceptible (S) and tolerant (T) fruits and further analyzed by qRT PCR. Finally, 40 genes have been nominated as genes expressed during chilling injury process. A total of 40 candidate genes were selected based on their annotation according to their potential role in $\mathrm{Cl}$ with functional category (1) Cell wall structure and secondary metabolism, (2) Response to stress and cellular homeostasis, (3) Response to RNA transcription and regulation, (4) Protein degradation and signal transduction pathway.

\section{Molecular marker and Genotyping}

40 SSR primer pairs were designed for 40 CGs resulted from Granell study (unpublished data), designed using Primer3 software [24]. Fragment size polymorphism of targeted gene fragments was observed as reproducible marker polymorphism on the PAGE profiles of the CGs PCR products. $P C R$ reaction mixture included $10 \mathrm{ng} / \mu \mathrm{l}$ genomic DNA, 10 $\mathrm{mM}$ dNTPs $0.5 \mathrm{ul}$ (dNTP Mix PCR grade, Qiagen), 5 units/ $\mu$ l of Taq $0.1 \mu \mathrm{l}$ (Taq DNA polymerase, Qiagen), $0.03 \mu \mathrm{l}$ of forward, $0.112 \mu$ l of IRD 700 (IRDye 700 phosphoramidite, LI-COR ${ }^{\circledR}$ Biosciences), IRD 800 (IRDye 800 phosphoramidite, LI-COR ${ }^{\oplus}$ Biosciences), $0.112 \mu \mathrm{l}$ of reverse primers (10 $\mu \mathrm{M}$ per each), $10 \mathrm{X}$ buffer $1.4 \mu \mathrm{l}$ and $\mathrm{ddH} 2 \mathrm{O}$ was used to bring final volume of $10 \mu \mathrm{l}$. PCR condition included initial denaturation step at $94^{\circ} \mathrm{C}$ for $5 \mathrm{~min}$, then $30 \mathrm{cycles}$ of $\left(94^{\circ} \mathrm{C}\right.$ for $30 \mathrm{sec}, 57^{\circ} \mathrm{C}$ for $35 \mathrm{sec}, 72^{\circ} \mathrm{C}$ for $\left.45 \mathrm{sec}\right)$ and then $8 \mathrm{cycles}$ of $\left(94^{\circ} \mathrm{C}\right.$ for $30 \mathrm{sec}$, $57^{\circ} \mathrm{C}$ for $35 \mathrm{sec}, 72^{\circ} \mathrm{C}$ for $45 \mathrm{sec}$ ) and final elongation at $72^{\circ} \mathrm{C}$ for $30 \mathrm{~min}$ and $4^{\circ} \mathrm{C}$ forever. Only polymorphic primers and SSR markers used for genetic mapping are shown (Table 1).

\section{PAGE analysis}

The $1 \mu \mathrm{l}$ of PCR product was mixed with $4 \mu \mathrm{l}$ of LiCOR dye (LI-COR, Inc. Lincoln, NB) A $6 \%$ polyacrylamide gel [21 ml of 7M UREA solution, $4 \mathrm{ml}$ of $30 \%$ Bis- acryl amide, 150 $\mathrm{ml}$ of $10 \%$ APS $(0.1 \mathrm{~g}$ Ammonium per sulphate to $1.0 \mathrm{ml}$ deionized water in a small test tube) and 15 ul of TEMED before pouring the gel] was used. From $5 \mu \mathrm{l}$ of sample 
Table 1. Name of candidate genes along with their primer sequence, amplicon size and SSRs marker information for Pop-DG

\begin{tabular}{|c|c|c|c|c|c|c|}
\hline S No. & $\begin{array}{l}\text { Primer } \\
\text { Name }\end{array}$ & Forward (5'-3') & Reverse $\left(5^{\prime}-3^{\prime}\right)$ & $\begin{array}{l}\text { Temp } \\
\left({ }^{\circ} \mathrm{C}\right)\end{array}$ & $\begin{array}{l}\text { Amplicon } \\
\text { Size (bp) }\end{array}$ & $\begin{array}{l}\text { Polymor- } \\
\text { phism } \\
\text { type }\end{array}$ \\
\hline 1 & CG1 & GCTGATTACATGTAAGTACTCAAGG & GTAGCCTCACTGCAAAGGTAT & 57 & 291 & SSR \\
\hline 2 & CG2 & AАCСТCTCCAGAATACСACTC & TATTTCAAGAGCTGAGTTTGG & 57 & 218 & SSR \\
\hline 3 & CG5 & TAGAGACAGCAAACAGAGGAA & AАACССАТСТTCTGCTTCTAC & 57 & 129 & SSR \\
\hline 4 & CG6 & TTCTGGTACCGAACGAAA & AGCACTAATCAGCTCCTAA & 57 & 138 & SSR \\
\hline 5 & CG7 & GGCGCTTCCTCCTTATACAAC & GATCTGGCCGAGACTGAATG & 57 & 201 & SSR \\
\hline 6 & CG12 & ATGAAGAGTTTGTGGCAAGG & CСАСТTCATTCACAATCACG & 57 & 211 & SSR \\
\hline 7 & CG14 & GAGGTGTTGGAACCATCAAG & GGTAGTTGCTGGTGCTCTTT & 57 & 219 & SSR \\
\hline 8 & CG16 & CGGTCAATCTTCCGATATTC & TTCCTCGCTCATATTGGACT & 57 & 205 & SSR \\
\hline 9 & CG18 & AGTCCCTGGATTCCTCAAA & ACACACGAGTGACCAGCA & 57 & 257 & SSR \\
\hline 10 & CG19 & CGTGAAGAAGCCTCACAGA & TCСТCAAАCAACССАACAA & 57 & 216 & SSR \\
\hline 11 & CG30 & ATTGCAACGGAAACCAACT & AATGCGTGGATCGTTCTTT & 57 & 248 & SSR \\
\hline 12 & CG31 & AAGGGTCATGTGACCTGCT & AGTCGAAGCCATTAATGCAG & 57 & 248 & SSR \\
\hline 13 & CG36 & CTAAGAGACCCGAGGTTGAAG & AGCTTCATGTCTGTCAAGTGG & 57 & 242 & SSR \\
\hline 14 & CG37 & GACAGCAAAAACGAAGGTTG & TACGGCTCTTGTTCTTGTCC & 57 & 288 & SSR \\
\hline 15 & CG38 & AGTTCTTCAGATGCCAACCAT & TTGTCCCTGTCTTCATCCAT & 57 & 299 & SSR \\
\hline \multirow[t]{2}{*}{16} & CG40 & GAAGCCTGCCATTGATTCTA & ATCTCGCGTAATGTCTCCAC & 57 & 248 & SSR \\
\hline & SSRs & Forward (5'-3') & Reverse (5'-3') & $\begin{array}{l}\text { Temp } \\
\left({ }^{\circ} \mathrm{C}\right)\end{array}$ & $\begin{array}{l}\text { Amplicon } \\
\text { Size (bp) }\end{array}$ & $\begin{array}{l}\text { Polymor- } \\
\text { phism } \\
\text { type }\end{array}$ \\
\hline 1 & ВРРСТ-021 & TGCATGAGAAACTTGTGGC & CCAAGAGCCTGACAAAGC & 57 & 288 & SSR \\
\hline 2 & ВРРСТ-020 & CGTGGATGGTCAAGATGC & ATTGACGTGGACTTACAGGTG & 57 & 216 & SSR \\
\hline 3 & ВРPCТ-021B & TGCATGAGAAACTTGTGGC & CCAAGAGCCTGACAAAGC & 57 & 248 & SSR \\
\hline 4 & UCDCH15 & TGCATGAGAAACTTGTGGC & CCAAGAGCCTGACAAAGC & 57 & 248 & SSR \\
\hline 5 & ВРРСТ-036 & AAGCAAAGTCCATAAAAACGC & GGACGAAGACGCTCCATT & 57 & 248 & SSR \\
\hline 6 & ВРРСТ-015 & ATGGAAGGGAAGAGAAATCG & GTCATCTCAGTCAACTTTTCCG & 57 & 129 & SSR \\
\hline 7 & ВРРСТ-026 & ATACCTTTGCCACTTGCG & TGAGTTGGAAGAAAACGTAACA & 57 & 138 & SSR \\
\hline 8 & ВРРСТ-017 & TTAAGAGTTTGTGATGGGAACC & AAGCATAATTTAGCATAACCAAGC & 57 & 218 & SSR \\
\hline
\end{tabular}

only $0.5 \mu \mathrm{l}$ of PCR product was loaded in gel. The LI-COR 4200 Series instrument was used to run gel according to manufacturer instructions (LI-COR, Inc. Lincoln, NB). Gel scoring was done both manually and by using Gel buddy software [25].

Candidate gene selection from CI-susceptible 'hermoza' and CI-resistant 'oded' peaches

Transcriptomic analyses [23] conducted on two peach cultivars, which differ in their resistance to chilling injury, were examined after two weeks of cold storage at $5^{\circ} \mathrm{C}$ by using ChillPeach cDNA microarray platform. One hundred and two CGs (Supplementary table 1) were obtained from this transcriptomic analysis of two peach cultivars which were white and melting-flesh, however 'Oded' (Prunus persica cv.
Oded), is a cling-stone, early season peach while 'Hermoza' (P. persica cv. Hermoza), is a free-stone, mid-season cultivar.

Physical position of the CGs and SNPs markers

SNPs markers were obtained from both parents from our previous work [26]. The peach "GS0012410-OPA. opa" consisted of 1,536 SNPs and was used to genotype Pop-DG population. The selection of high quality SNPs and genotyping of Pop-DG was carried out and high quality SNP map was created [22]. The SNPs and the two set of CGs obtained from the two different sources were ordered by reference to their position using the 'Lovel' using "peach v1.0" reference genome (released by the International Peach Genome Inititative (IPGI) in 2010). Additional to 40 CGs from our first source (Granell, unpublished) and 102 CGs from 
Table 2. Features of candidate genes with their functional annotation of Pop-DG. The list shows name of 50 CGs with their unigene functional annotation and their position in scaffolds of peach genome. 40 CGs were from transcriptomic analysis of Pop-DG. 10 CGs (41-50) were from other published sources

\begin{tabular}{|c|c|c|c|c|c|c|}
\hline S.No. & $\begin{array}{l}\text { Name of } \\
\text { CGs in } \\
\text { mapping } \\
\text { and } \\
\text { scaffolds }\end{array}$ & $\begin{array}{l}\text { Name of } \\
\text { Candidate } \\
\text { Genes from } \\
\text { transcriptomic } \\
\text { analysis }\end{array}$ & Source & $\begin{array}{l}\text { Similar } \\
\text { Prunus } \\
\text { persica DNA } \\
\text { sequence ID }\end{array}$ & Unigene Functional Annotation & $\begin{array}{l}\text { Position in scaffolds of peach } \\
\text { genome }\end{array}$ \\
\hline 1 & CG1 & PPLDOX & Chill Peach & ABX89943 & Leucoanthocyanidin dioxygenase gene & scaffold_5:9,817,818..9,819,338 \\
\hline 2 & CG2 & PPN011D08 & Chill Peach & BU044303 & Phi-1 protein & scaffold_1:18,494,503..18,502,877 \\
\hline 3 & CG3 & PPN059B10 & Chill Peach & NA & Os01g0186900 protein & scaffold_7:19,378,715..19,379,406 \\
\hline 4 & CG4 & PPN038D06 & Chill Peach & DW341257 & Glycosyltransferase QUASIMODO1 & scaffold_8:18,126,089..18,127,289 \\
\hline 5 & CG5 & PP1004C04 & Chill Peach & DN676686 & Mannan endo-1,4-beta-mannosidase & scaffold_1:21,828,585..21,829,753 \\
\hline 6 & CG6 & PPN040G09 & Chill Peach & NA & Cell cycle checkpoint protein RAD17 & scaffold_7:17,694,654..17,695,645 \\
\hline 7 & CG7 & PP1002E07 & Chill Peach & AJ824111 & Omega- 6 fatty acid desaturase & scaffold_7:10,931,319..10,934,687 \\
\hline 8 & CG8 & PP1001G06 & Chill Peach & P43297 & Cysteine protease $\mathrm{CP} 1$ & scaffold_1:22,788,451..22,790,193 \\
\hline 9 & CG9 & PP1001A05 & Chill Peach & P51846 & Pyruvate decarboxylase 1 & scaffold_6:24,372,690..24,377,696 \\
\hline 10 & CG10 & PP1001C07 & Chill Peach & DY649642 & Mitochondrial pyruvate dehydrogenase kinase isoform 2 & scaffold_1:8,042,187..8,043,567 \\
\hline 11 & CG11 & PP1003F01 & Chill Peach & DY641887 & 4-coumarate-CoA ligase-like protein & scaffold_5:10,637,165..10,637 \\
\hline 12 & CG12 & PPN004H06 & Chill Peach & AB044662.1 & 1-aminocyclopropane-1-carboxylate synthase 1 & scaffold_2:18,502,578..18,502,877 \\
\hline 13 & CG13 & PP1001C04 & Chill Peach & DY643195 & Ring zinc finger protein & scaffold_6:5,374,851..5,376,021 \\
\hline 14 & CG14 & PPN045B08 & Chill Peach & BU043492 & Major cherry allergen Pru av 1.0203 & scaffold_1:9,560,967..9,566,560 \\
\hline 15 & CG15 & PP1004E08 & Chill Peach & DY650607 & AT3g15350/K7L4_15 & scaffold_4:10,707,438..10,709,198 \\
\hline 16 & CG16 & PPN009B03 & Chill Peach & NA & Chlorohydrolase family protein & scaffold_1:22,614,349..22,615,237 \\
\hline 17 & CG17 & PPN025B02 & Chill Peach & BU040021 & similar to Cyclic nucleotide-gated ion channel 1 & scaffold_8:12,221,208..12,222,294 \\
\hline 18 & CG18 & PPN070C12 & Chill Peach & DW346523 & PP_LEc0008N19f Peach shoot Prunus persica & scaffold_3:9,394,101..9,394,881 \\
\hline 19 & CG19 & PPN032H11 & Chill Peach & BU041375 & Histone protein Hist $2 \mathrm{~h} 3 \mathrm{cl}$ & scaffold_1:22,024,422..22,025,550 \\
\hline 20 & CG20 & PP1002D01 & Chill Peach & AJ822461 & Putative ripening-related protein & scaffold_6:23,110,781..23,111,935 \\
\hline 21 & CG21 & PPN012B10 & Chill Peach & DY644352 & Putative ripening-related protein & scaffold_6:23,110,786..23,112,557 \\
\hline 22 & CG22 & PP1001B03 & Chill Peach & DY639769 & Os04g0623400 protein & scaffold_6:26288000..26289999 \\
\hline 23 & CG23 & PP1005B08 & Chill Peach & NA & Unknown & scaffold_4:17436741...17438740 \\
\hline 24 & CG24 & PPN075H08 & Chill Peach & DY642462 & Os01g0818000 protein & scaffold_6:25353012..25355011 \\
\hline 25 & CG25 & PPN032A07 & Chill Peach & DW347694 & T23O15.3/T23O15.3 & scaffold_3:15336089..15338088 \\
\hline 26 & CG26 & PPN078F09 & Chill Peach & DY638908 & Protease-associated PA & scaffold_1:22011177..22025550 \\
\hline 27 & CG27 & PPN054B03 & Chill Peach & DY639769 & CBF1 & scaffold_2:24800744..24802743 \\
\hline 28 & CG28 & PPN054B07 & Chill Peach & DY640636 & Calcium-binding EF-hand & scaffold_4:11650422...11652421 \\
\hline 29 & CG29 & PPN003H11 & Chill Peach & DY641715 & Cinnamoyl-CoA reductase-like protein & scaffold_1:7494927..7496926 \\
\hline 30 & CG30 & PP1002E04 & Chill Peach & AF362990.1 & Alpha-L-arabinofuranosidase / beta-D-xylosidase & scaffold_1:9204523..9206522 \\
\hline 31 & CG31 & PP1005H08 & Chill Peach & NA & No annotation available & scaffold_7:15559769..15564768 \\
\hline 32 & CG32 & PPN005G05 & Chill Peach & DY653721 & Anther ethylene-upregulated protein ER & scaffold_1:8242276..8244275 \\
\hline 33 & CG33 & PPN039H11 & Chill Peach & DY637895 & Glutathione S-transferase & scaffold_3:95408..97407 \\
\hline 34 & CG34 & PPN070G08 & Chill Peach & DY634402 & Beta-galactosidase precursor (EC 3.2.1.23) (Lactase) & scaffold_7:19628203..19630202 \\
\hline 35 & CG35 & PP1009D05 & Chill Peach & DY645444 & Amino acid transporter & scaffold_1:30527322..30529321 \\
\hline 36 & CG36 & PPN023G06 & Chill Peach & DY646993 & Mi-2 autoantigen-like protein & scaffold_4:6182101..6184100 \\
\hline 37 & CG37 & PPN029B05 & Chill Peach & NA & No annotation available & scaffold_1:30527234..30529233 \\
\hline 38 & CG38 & PPN021B10 & Chill Peach & DY648396 & similar to Location of EST 206I21T7 & scaffold_5:12724586..12726585 \\
\hline 39 & CG39 & PPN021G05 & Chill Peach & NA & Armadillo & scaffold_4:1774113..1776112 \\
\hline 40 & CG40 & PPN037E06 & Chill Peach & AJ827029 & RSI-1 protein precursor & scaffold_3:12708896..12710895 \\
\hline S.No. & $\begin{array}{l}\text { Name of } \\
\text { CGs in } \\
\text { mapping } \\
\text { and scaf- } \\
\text { folds }\end{array}$ & $\begin{array}{l}\text { Name of Can- } \\
\text { didate Genes } \\
\text { from other } \\
\text { sources }\end{array}$ & Source & $\begin{array}{l}\text { Similar } \\
\text { Prunus } \\
\text { persica DNA } \\
\text { sequence ID }\end{array}$ & Unigene Functional Annotation & $\begin{array}{l}\text { Position in scaffolds of peach } \\
\text { genome }\end{array}$ \\
\hline 41 & CG41 & PPN003H07-1 & Chill Peach & AF362987 & Thaumatin-like 1 protein & scaffold_7:8543779..8545778 \\
\hline 42 & CG42 & PPN003H07-2 & Chill Peach & AF362988 & Thaumatin-like 2 protein & scaffold_3:9873109..9875108 \\
\hline 43 & CG43 & CL1439Contig1 & Chill Peach & DQ251187 & major allergen Pru p 1 & scaffold_1:9586936..9597544 \\
\hline 44 & CG44 & PP1001B08 & Chill Peach & AF367443 & NADP-dependent isocitrate dehydrogenase & scaffold_3:242975..247974 \\
\hline 45 & CG45 & CL417Contig1 & Chill Peach & BU043362 & Pectate lyase & scaffold_6:22023991..22025990 \\
\hline 46 & CG46 & PPN002G04 & Chill Peach & X95991 & Pectinesterase & scaffold_7:18644917..18650259 \\
\hline 47 & CG47 & PP1006B11-1 & Chill Peach & AF367459 & PpExp1, expansin 1 & scaffold_1:22788899..22790898 \\
\hline 48 & CG48 & PP1006B11-2 & Chill Peach & AB047518 & PpExp2, expansin 2 & scaffold_1:27209405..27211404 \\
\hline 49 & CG49 & CL971Contig1 & Chill Peach & АВ047519 & PpExp3, expansin 3 & scaffold_6:5141253..5143970 \\
\hline 50 & CG50 & PP1006B11-3 & Chill Peach & AB054319 & PpExp4, expansin 4 & scaffold_3:19591237..19593236 \\
\hline
\end{tabular}


second source [23], 10 more CGs (Table 2) were nominated from published works and review articles of physiology and transcriptomic study of peach fruit subjected to $\mathrm{Cl}$.

\section{Linkage analysis}

The two classes of marker data (SSR and SNP) that showed mendelian segregation were used for linkage analysis using JoinMap ${ }^{\circledR} 4$ [24]. The marker data type was coded as cross pollination in JoinMap ${ }^{\oplus} 4$ and maps were calculated without adding the marker order into the scaffolds. Linkage parameters were set as 3.0 minimum LOD and 0.45 maximum recombination fraction were used as thresholds [20]. The Kosambi mapping function [27] was used to convert recombination fraction to map distances in centimorgans (cM). Graphical presentation and their alignment were performed using Map chart 2.2 [28].

\section{Results}

Primer design and marker polymorphism

Among the 40 SSR primer pairs designed (Table 1) for 40 CGs resulted from the transcriptomic analysis, only polymorphic primers were used in the present study for CGs mapping. SSRs were first studied in the parents, the six plants of the progeny to detect polymorphism. Polymorphic and well amplified markers were later run with the whole population of 51 progeny. Sixteen primers were polymorphic between the parents and also segregated in the progeny. Seven primers showed polymorphism in parents, but not in the progeny. The remaining 17 primers showed monomorphic bands and not segregated in the progeny. The proportion of SSRs giving polymorphism for $\mathrm{Cl}$ was lower than expected from our previous study [20].

For the 16 CGs having polymorphism, were taken for mapping in F1 population in the Pop-DG. Four candidate genes were not mapped. The Pop-DG intraspecific peach linkage analysis resulted in a total of 12 CGs with 17 SSR and 31 SNPs flanking and QTL significant makers distributed over five linkage groups corresponding to the haploid chromosome number of peach (Figure 1). The common SSR markers enabled the determination of linkage group orientation and assignment of linkage group numbers for the Pop-DG map. Among the twelve CGs, seven were localized on Pop DG linkage group LG1 (CG2, CG14, CG5, CG16, CG30, CG37 and CG19), one on LG3 (CG18), one on LG4 (CG36), two on LG5 (CG1 and CG38) and one on LG7 (CG7). Previously identified QTLs significant markers [22] for mealiness (qML1 and qML4.1), flesh bleeding (qBLa, $q B L b, q B L c$ and $q B L 4)$ and browning ( $q B r L 5)$ were in $L G 1$, LG4 and LG5 respectively. The most significant markers for all above traits were mapped along with candidate genes identified in this study (Figure 1).

Association of CGs with SNP linkage map of Pop-DG Genetic linkage analysis using SNP markers constructed [22] for Pop-DG ('Dr. Davis' x 'Georgia Belle') was used for association of CGs localized in this study with selected significant markers identified previously. Both sets of genotyping data were loaded into Join-Map ${ }^{\circledR} 4$ and map was constructed with CGs and SNP markers together (data not shown). When nearby flanking markers and $\mathrm{Cl}$ QTL significant markers were identified, the final map was constructed only with CGs and nearby flanking markers. For each candidate genes on the linkage group at least two flanking SNP markers were identified.

\section{Sequence blast and localization in Prunus genome}

Table 3. Different fruit quality characteristics of Pop-DG parental cultivars, 'Dr. Davis' and 'Georgia Belle'

\begin{tabular}{llll}
\hline S.No. & Trait/Character & 'Dr. Davis' & 'Georgia Belle' \\
\hline 1 & Ripening date & Later & Earlier \\
2 & Skin color & Orange ground, with blush & Green/yellow, no blush \\
3 & Flesh color & Yellow -orange & White-cream \\
4 & Stone adhesion & Clingstone & Freestone \\
5 & Flesh texture & Firm, non meting flesh & Soft, melting flesh \\
6 & Aroma & Bland & Sharp \\
7 & Sweetness (SSC) & 11.5 & 13.0 \\
8 & Acidity (TA) & High & Low \\
9 & Mealiness & None & High susceptibility \\
10 & Browning & Medium susceptibility & High susceptibility \\
11 & Bleeding & High susceptibility & Low susceptibility \\
\hline
\end{tabular}

$\mathrm{TA}=$ Titratable acidity, SSC $=$ soluble solids content 
LG 1

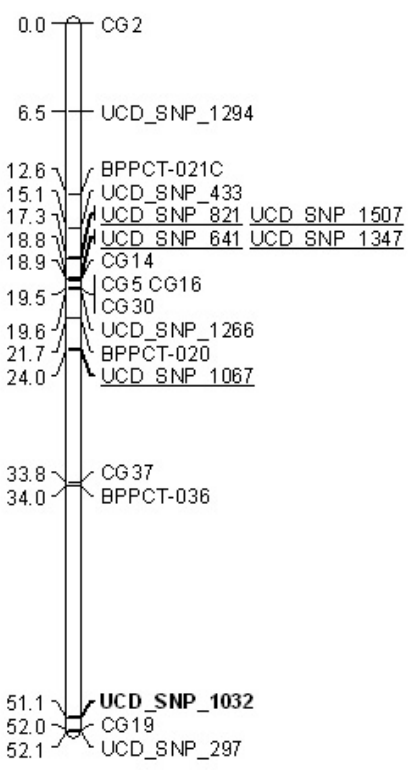

LG 3

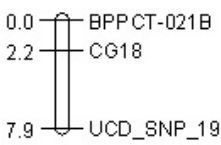

LG 4

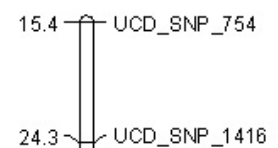

$24.87-\mathrm{UCDCH}^{2} \mathrm{H}^{-}$

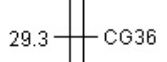

$35.9-$ UCD SNP 1084 UCD SNP 1441 $37.7-$ UCD_SNP_56
LG 5

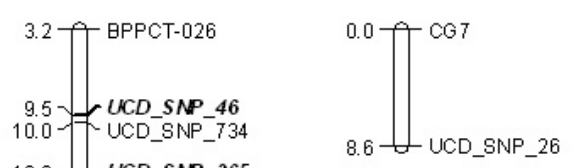

Figure 1. Candidate Gene map of Pop-DG with flanking SSRs, SNPs and QTLs significant SNP markers constructed using JoinMap ${ }^{\circledR}$ 4.0. The Genetic distance in the Pop-DG map is shown in centimorgans (cM) on left side. The location of all candidate genes mapped in Pop-DG agreed with the positions of their homologous sequences in corresponding peach genome scaffolds. Significant markers for various CI traits are mapped. Underlined font denotes flesh bleeding; bold font for mealiness; bold and underlined for both mealiness and flesh bleeding; bold italic font denotes flesh browning.

Sequences of the 40 CGs from first source of study, 102 CGs and other 10 nominated CGs were blasted against peach genome v1.0 scaffolds (http://www.phytozome.net/ search.php?show=blast\&method=Org Ppersica), and the resulting homolog sequences were located in the scaffolds (corresponding to the linkage groups of Prunus genetic maps) using the GBrowse function in website http://www. phytozome.net/cgi-bin/gbrowse/peach/. The position of each CGs on scaffold only with nearest SNP marker is shown in Figure 2 and Figure 3.

\section{Discussion}

Influence of year and genetic factors on $\mathrm{Cl}$ susceptibility in peach have been well reviewed in our previous work [29]. Thus $\mathrm{Cl}$ resistance is thus a viable long-term strategy to reduce losses in the fresh and processed peach and nectarine industries. We have mapped CGs and created a preliminary $\mathrm{Cl}$ linkage map for Peach. We have 26 SNPs and 8 SSRs flanking markers with 12 CGs mapped on Pop-DG using SSR marker. Simple sequence repeats (SSRs) have proven to be highly polymorphic, easily reproducible, codominant markers. However, developing an SSR map is very time-consuming and expensive atleast for candidate genes. A number of SSR markers for Prunus persica and other species of the same genus are available for different purposes [30-33].

Data from study in Pop-DG population for fruit quality gene map of prunus showed that the polymorphism was $\sim 50 \%$ [34], lower than the observed in TXE ( 85\%), but higher than the observed for Pop-DG ( 25\%). The lower rate of polymorphism observed in 'Venus' $\times$ 'Big Top' $(\mathrm{V} \times \mathrm{BT})$ and Pop-DG compared to TXE could be explained since TXE is a F2 population from an inter-specific cross. A genetic linkage map of linkage group 4 (LG4) was constructed with SSR and candidate genes from a segregating population developed using the cross 'Venus' $\times$ 'BigTop'. Significant quantitative trait loci (QTLs) for mealiness, graininess, leatheriness and bleeding were found in this linkage group, validating QTLs for $\mathrm{Cl}$ symptoms previously reported in this linkage group from an unrelated progeny population $[20,35]$.

The first source of 40 candidate genes was from transcriptomic analysis conducted on Pop-DG population. SSR primers designed for 40 candidate genes resulted in only 16 polymorphic markers and among them only 12 were mapped in five linkage groups, 7 were localized on LG1. The blast search of $40 \mathrm{CG}$ and resulting homologous sequence showed that these genes were scattered all over the eight scaffolds of peach genome with scaffold 1 harboring 13 CGs. 


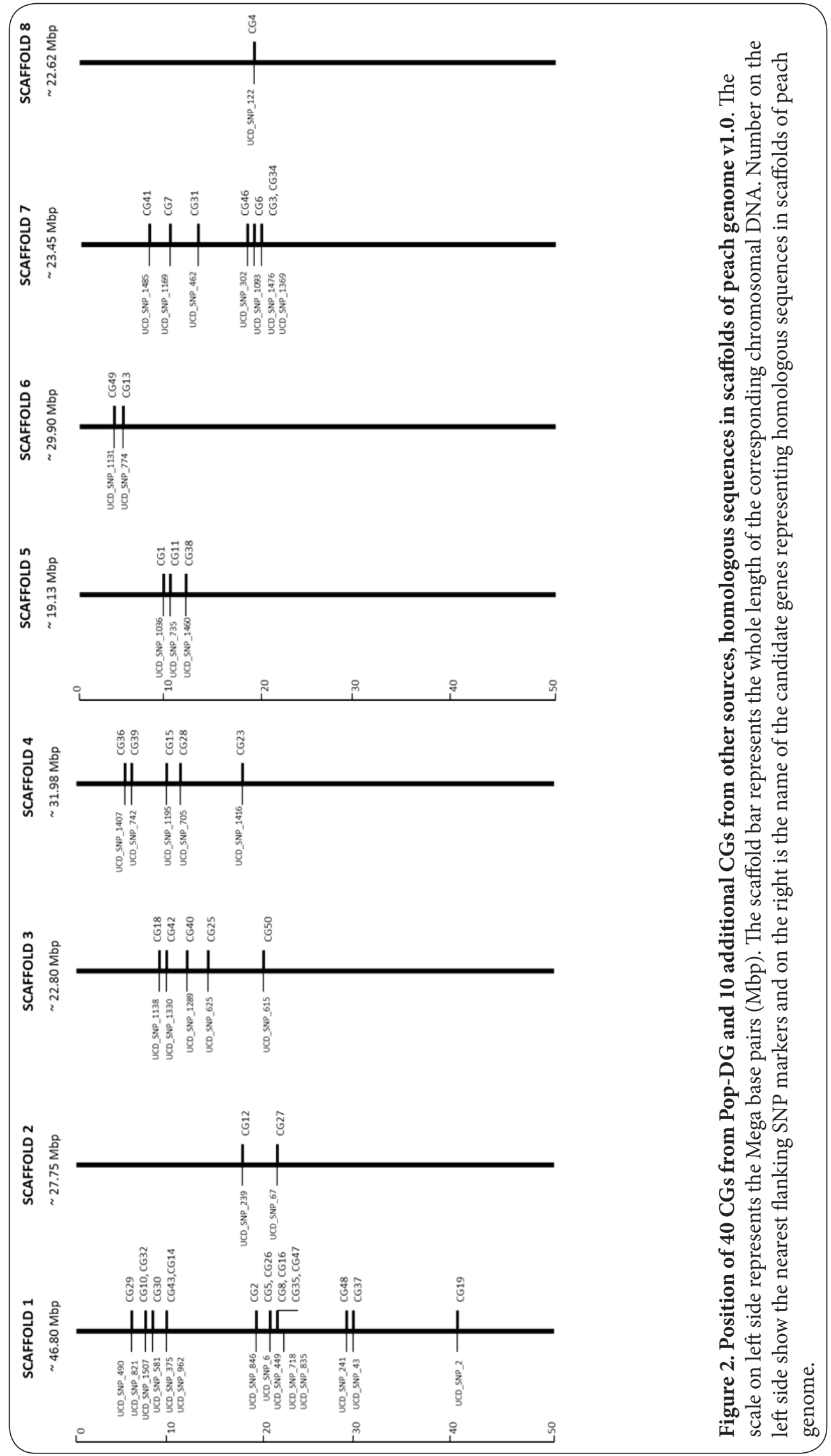


Dhanapal et al. Journal of Plant Science \& Molecular Breeding 2012,

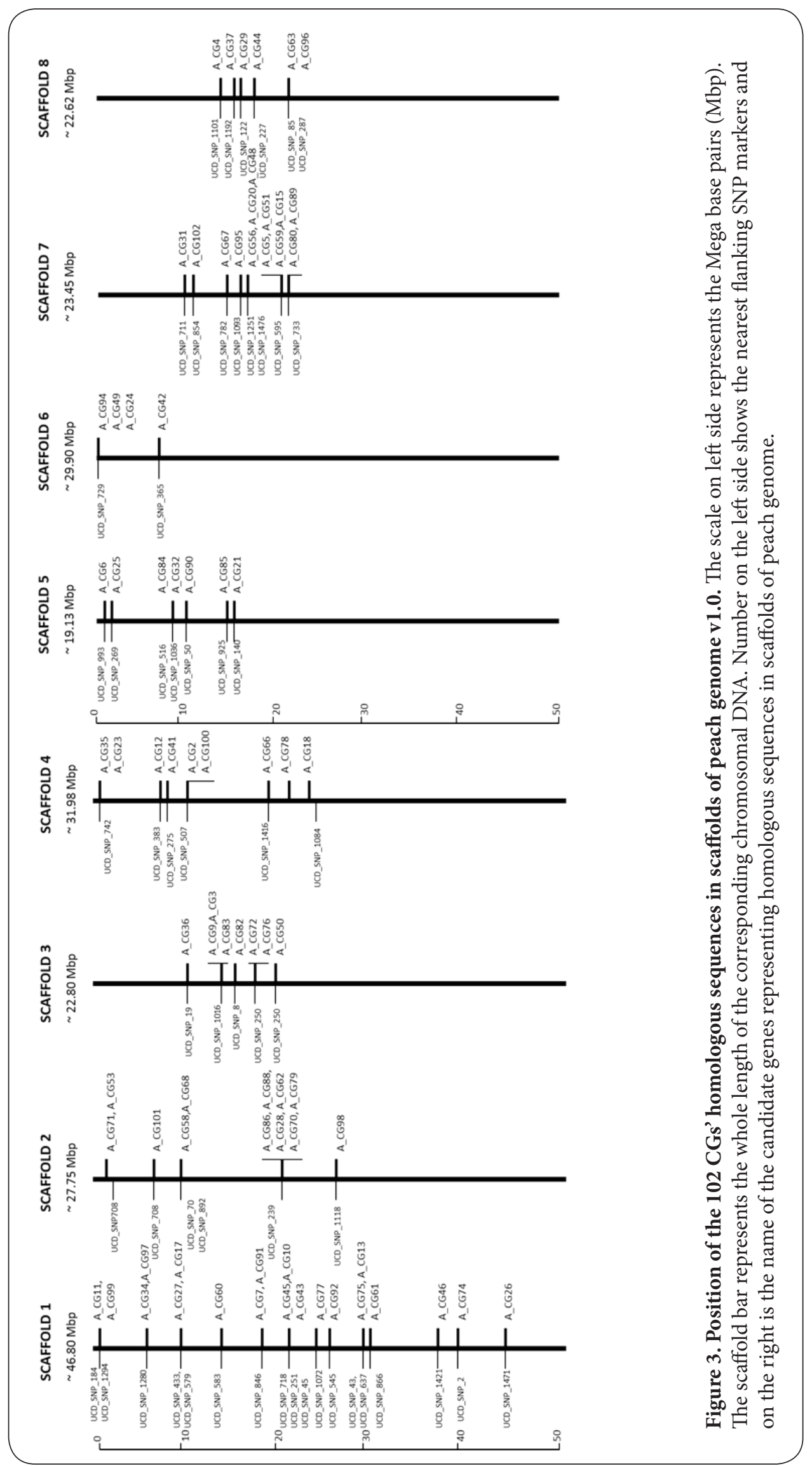


Among 10 additionally selected CGs three of them have their homologous sequence in scaffold 1. This result shows CGs mapped on Pop-DG and CGs localized on peach scaffolds, among which major number of genes were mapped and localized on LG1 and scaffold 1. For total of 50 CGs, 41 CGs were localized in all eight scaffolds of peach genome with at least one flanking SNP marker based on their scaffold position (Figure 2).

The 102 CGs from transcriptomic analyses of two peach cultivars Oded and Hermoza, which differ in their resistance to chilling injury, formed the second source of CGs. Blast search of their homologous sequence showed that all the 102 CGs were scattered all over the 8 scaffolds of peach genome (Supplementary table 2). Among the genes localized, about 20 CGs were localized in scaffold 1. In scaffold 2 SNP marker UCD_SNP_239 was the flanking marker for six CGs. In total, of 102 CGs, 79 CGs were localized in 8 scaffolds of peach genome with at least one flanking SNP marker based on their scaffold position (Figure 3). Even though in our present study among the 40 SSR markers designed for CGs only, 16 SSRs were polymorphic. Result of our present study shows that other markers systems such as Single nucleotide polymorphism (SNPs) should be used for CGs mapping in order to increase the number of polymorphic markers and get other CGs mapped.

The previously identified QTL for browning on LG5 [36] was compared to location of candidate gene CG1 (PpLDOX) and this co-location implies the control of QTL by that particular gene and SNP marker UCD_SNP_78 was closely linked to this CG1. Previously identified CGs $[18,20,36-38]$ for mealiness and flesh bleeding on LG1 and LG4 and flesh browning in LG5 and most significant markers [22], identified were mapped along with CGs in our present study. QTLs identified for mealiness (qML1; LOD score 4.18) at $51.06 \mathrm{cM}$ in LG1 was close to presently mapped CG19 at $52.0 \mathrm{cM}$ with flanking marker UCD_SNP_297. Another QTL for mealiness (qML4.1;LOD score 8.74) at 35.89 cM in LG4 was $6.6 \mathrm{cM}$ away from CG36. Four QTLs identified for flesh bleeding in which three in LG1 [qBLa (17.28cM); LOD score 3.86 , qBLb (18.80cM); LOD score 3.19, and qBLc (23.96cM); LOD score 3.22] were close to CG14 (18.9cM), CG5 (19.5cM), CG16 (19.5cM) and CG30 (19.5cM). One QTL identified in LG4 (qBL4; LOD score 4.45) at 35.89 cM was $6.5 \mathrm{cM}$ away from CG36 [22].

More than one significant marker associated with QTL was identified for flesh browning in LG5 (qBrL5) in previous study [22]. CG1 was at same position of significant marker identified (UCD_SNP_1422) for flesh browning and CG38 was $4.5 \mathrm{cM}$ away from qBrL5. The major QTL for mealiness was validated in $\mathrm{V} \times \mathrm{BT}$ population and QTL for browning not found on our previous work on LG4 [35] was found in Pop-DG [22]. Location of candidate gene Thaumatin-like protein 1 precursor from our previous study [36] was compared to the scaffold location of CG41 from the present study and this implies its co-location of this gene. Recent comparative study of melting and non-melting flesh peach cultivars reveals that during fruit ripening endo-PG is mainly involved in pericarp textural changes, not in firmness reduction [39].

\section{Conclusion}

Results showed that in total of 152 CGs, $(40+102+10)$ major numbers of CGs were localized on scaffold 1. The markers localized in this manner may provide additional information for peach physical mapping efforts. Although this is a preliminary data showing the location of CGs in scaffolds of peach genome, detailed study of this CGs in mapping population of peach will determine their applicability as potential CGs for marker assisted breeding (MAB). Knowledge of the genetic basis of $\mathrm{Cl}$ traits and their linkage with SSR and SNP markers permit a more realistic estimate of the effort needed to produce a new cultivar with $\mathrm{Cl}$ resistance. Such information also reduces the labor and time required to develop cultivars and improves the accuracy of marker-assisted selection (MAS). Field evaluation is limited to trees containing the genes of interest, significantly reducing the costs associated with maintaining undesirable trees to maturity. The CGs mapped in Pop-DG in this study can be used as potential markers to preselect seedlings for $\mathrm{Cl}$ fruit traits such as mealiness, flesh bleeding and flesh browning, while also speeds the development of commercially acceptable cultivars with minimum deterioration or no deterioration. Our future efforts will be to map all the CGs from both sources by SNP or SSCP based marker system.

\section{Additional files

\begin{tabular}{|l} 
Supplementary table 1 \\
Supplementary table 2
\end{tabular}

\section{Competing interests}

The Author's declare that they have no competing interests.

\section{Authors' contributions}

APD organized the plant materials, designed experiments, carried out molecular genetic studies and drafted the manuscript. APD performed all data analysis along with PMG. TMG provided plant materials. APD and $\mathrm{CHC}$ revised critically the manuscript. CHC provided financial support to the study. All authors read, discussed and approved the final manuscript.

\section{Acknowledgements and funding}

We gratefully acknowledge the assistance of DNA Technologies Core at the University of California, Davis as well as the support of the National Research Initiative of USDA's National Institute of Food and Agriculture (NIFA) grant \# 2008-35300-04432 and US-Israel Bi-national Agriculture Research and Development Fund (BARD) Grant no. US-402707 for provided financial support to this project, as well as UC Davis, UC Agricultural Experiment Station and USDA-CREES 
(Hatch Experiment Station funding). Authors thank Helen Chan laboratory assistant at UC Davis, for her collaboration in lab work. We gratefully acknowledge Dr. Antonio Granell Richart for his collaboration in sharing candidate genes data of Pop-DG. We would also especially like to thank Dr. Anurag Dagar and Dr. Susan Lurie for their collaboration in sharing candidate gene data of Hermoza and Oded peach cultivar.

Publication history

Received: 11-Aug-2012 Revised: 25-Sep-2012

Accepted: 10-10-2012 Published: 27-Oct-2012

\section{References}

1. Abbott AG, Lecouls AC, Wang Y, Georgi L, Scorza R, Reighard G: Peach: The model genome for Rosaceae genomics. Acta Hortic 2002; 592;199-203. | Book

2. Shulaev V, Korban SS, Sosinski B, Abbott AG, Aldwinckle HS, Folta KM, lezzoni A, Main D, Arus P, Dandekar AM, Lewers K, Brown SK, Davis TM, Gardiner SE, Potter D, Veilleux RE: Multiple models for Rosaceae genomics. Plant Physiol 2008, 147:985-1003. | Article | PubMed Abstract | PubMed Full Text

3. Lurie $\mathrm{S}$, Crisosto $\mathrm{C}$ : Chilling injury in peach and nectarine. Postharvest Biol Tec 2005, 37:195-208. | Article

4. Crisosto $\mathrm{CH}$, Mitchell GF, Zhiguo J: Susceptibility to Chilling Injury of Peach, Nectarine, and Plum Cultivars Grown in California. Hort Science 1999, 34:1116-1118. | Article

5. Bruhn CM, Feldman N, Garlitz C, Hardwood J, Ivan E, Mar-shall M, Riley A, Thurber D, Williamson E: Consumer perceptions of quality: apricots, cantaloupes, peaches, pears, strawberries, and tomatoes. $J$ Food Qual 1991, 14:187-195. | Article

6. Brummell DA, Dal Cin V, Crisosto CH, Labavitch JM: Cell wall metabolism during maturation, ripening and senescence of peach fruit. J Exp Bot 2004, 55:2029-2039. | Article | PubMed

7. Brummell DA, Dal Cin V, Lurie S, Crisosto $\mathrm{CH}$, Labavitch JM: Cell wall metabolism during the development of chilling injury in cold-stored peach fruit: association of mealiness with arrested disassembly of cell wall pectins. J Exp Bot 2004, 55:2041-2052. | Article

8. Jarvis MC, Briggs SPH, Knox JP: Intercellular adhesion and cell separation in plants. Plant, Cell Environ 2003, 26:977-989. | Article

9. Zhou HW, Sonego L, Khalchitski A, Ben-Arie R, Lers A, Lurie S: Cell wall enzymes and cell wall changes in 'Flavortop' nectarines: mRNA abundance, enzyme activity, and changes in pectic and neutral polymers during ripening and in woolly fruit. J Am Soc Hortic Sci 2000, 125:630-637. | Article

10. Gonzalez-Aguero M, Pavez L, Ibanez F, Pacheco I, Campos-Vargas R, Meisel LA, Orellana A, Retamales J, Silva H, Gonzalez M, Cambiazo $\mathrm{V}$ : Identification of woolliness response genes in peach fruit after post-harvest treatments. J Exp Bot 2008, 59:1973-1986. | Article | PubMed Abstract | PubMed Full Text

11. Trainotti L, Zanin D, Casadoro G: A cell wall-oriented genomic approach reveals a new and unexpected complexity of the softening in peaches. J Exp Bot 2003, 54:1821-1832. | Article | PubMed

12. Brummell DA, Harpster MH: Cell wall metabolism in fruit softening and quality and its manipulation in transgenic plants. Plant Mol Biol 2001, 47:311-340. | Article | PubMed

13. Etienne C, Rothan C, Moing A, Plomion C, Bodenes C, Svanella-Dumas L, Cosson P, Pronier V, Monet R, Dirlewanger E: Candidate genes and QTLs for sugar and organic acid content in peach [ Prunus persica (L.) Batsch]. Theor Appl Genet 2002, 105:145-159. | Article | PubMed

14. Ogundiwin EA, Marti C, Forment J, Pons C, Granell A, Gradziel TM, Peace $\mathrm{CP}$, Crisosto $\mathrm{CH}$ : Development of ChillPeach genomic tools and identification of cold-responsive genes in peach fruit. Plant Mol Biol 2008, 68:379-397. | Article | PubMed

15. Vizoso P, Meisel LA, Tittarelli A, Latorre M, Saba J, Caroca R,
Maldonado J, Cambiazo V, Campos-Vargas R, Gonzalez M, Orellana A, Silva $\mathrm{H}$ : Comparative EST transcript profiling of peach fruits under different post-harvest conditions reveals candidate genes associated with peach fruit quality. BMC Genomics 2009, 10:423. | Article | PubMed Abstract | PubMed Full Text

16. Changfeng Z, Shiping T: Peach fruit acquired tolerance to low temperature stress by accumulation of linolenic acid and $\mathrm{N}$-acylphosphatidylethanolamine in plasma membrane. Food Chem 2010, 120:864-872. | Article

17. Ji-hao S, Jian-ye C, Jian-fei K, Chen WX, WJ L: Expression of sHSP genes as affected by heat shock and cold acclimation in relation to chilling tolerance in plum fruit. Postharvest Bio Tec 2010, 55:91-96. I Article

18. Peace $\mathrm{CP}$, Crisosto $\mathrm{CH}$, Gradziel TM: Endopolygalacturonase: a candidate gene for freestone and melting flesh in peach. $\mathrm{Mol}$ Breeding 2005, 16:21-31. | Article

19. Ogundiwin EA, Peace CP, Nicolet CM, Rashbrook VK, Gradziel TM, Bliss FA, Parfitt D, Crisosto $\mathrm{CH}$ : Leucoanthocyanidin dioxygenase gene (PpLDOX): a potential functional marker for cold storage browning in peach. Tree Genet Genom 2008b, 4:543-554. I Article

20. Ogundiwin EA, Peace CP, Gradziel TM, Parfitt DE, Bliss FA, Crisosto CH: A fruit quality gene map of Prunus. BMC Genomics 2009, 10:587. I Article | PubMed Abstract | PubMed Full Text

21. Callahan AM, Scorza R, Bassett C, Nickerson M, Abeles FB: Deletions in an endopolygalacturanase gene cluster correlate with nonmelting flesh texure in peach. Func Plant Biol 2004, 31:159-168. | Article

22. Martínez-García PJ, Parfitt DE, Ogundiwin EA, Fass J, Chan HM, Ahmad R, Lurie S, Dandekar A, Gradziel TM, Crisosto CH: High density SNP mapping and QTL analysis for fruit quality characteristics in peach (Prunus persica L.). Tree Genet \& Genom 2012, 1-18. | Article

23. Dagar A, Pons Puig C, Marti Ibanez C, Ziliotto F, Bonghi C, H. Crisosto C, Friedman H, Lurie S, Granell A: Comparative transcript profiling of a peach and its nectarine mutant at harvest reveals differences in gene expression related to storability. Tree Genetics \& Genomes 2012, 1-13. I Article

24. Rozen S, Skaletsky H: Primer3 on the WwW for general users and for biologist programmers. Methods Mol Biol 2000, 132:365-386. I Article I PubMed

25. Zerr T, Henikoff S: Automated band mapping in electrophoretic gel images using background information. Nucleic Acids Res 2005, 33:2806-2812. | Article | PubMed Abstract | PubMed Full Text

26. Ahmad R, Parfitt DE, Fass J, Ogundiwin E, Dhingra A, Gradziel TM, Lin D, Joshi NA, Martinez-Garcia PJ, Crisosto CH: Whole genome sequencing of peach (Prunus persica L.) for SNP identification and selection. BMC Genomics 2011, 12:569. | Article | PubMed Abstract I PubMed Full Text

27. Van Ooijen J: JoinMap ${ }^{\circledR}$ 4, Software for the calculation of genetic linkage maps in experimental populations. Kyazma BV, Wageningen, Netherlands 2006.

28. Voorrips RE: MapChart: software for the graphical presentation of linkage maps and QTLs. J Hered 2002, 93:77-78. | Article | PubMed

29. Martínez-García P, Peace C, Parfitt D, Ogundiwin E, Fresnedo-Ramírez J, Dandekar A, Gradziel T, Crisosto C: Influence of year and genetic factors on chilling injury susceptibility in peach (Prunus persica (L.) Batsch). Euphytica 2012, 185:267-280. | Article

30. Sosinski B, Gannavarapu M, Hager LD, Beck LE, King GJ, Ryder CD, Rajapakse S, Baird WV, Ballard RE, Abbott AG: Characterization of microsatellite markers in peach [Prunus persica (L.) Batsch]. Theor Appl Genet 2000, 101:421-428. | Article

31. Testolin R, Marrazzo T, Cipriani G, Quarta R, Verde I, Dettori MT, Pancaldi M, Sansavini S: Microsatellite DNA in peach (Prunus persica L. Batsch) and its use in fingerprinting and testing the genetic origin of cultivars. Genome 2000, 43:512-520. | Article | PubMed

32. Aranzana MJ, García-Mas J, Carbó J, and Arús P: Development 
and variability analysis of microsatellite markers in peach. Plant Breeding 2002, 121:87-92. | Article

33. Dirlewanger E, Cosson P, Tavaud M, Aranzana J, Poizat C, Zanetto A, Arus $\mathrm{P}$, Laigret F: Development of microsatellite markers in peach [ Prunus persica (L.) Batsch] and their use in genetic diversity analysis in peach and sweet cherry ( Prunus avium L.). Theor Appl Genet 2002, 105:127-138. | Article | PubMed

34. Abidi W, Cantín CM, Buhner T, Gonzalo MJ, Moreno MA, Gogorcena $Y$ : Genetic control and location of QTLs involved in antioxidant capacity and fruit quality traits in peach [Prunus persica (L.) Batsch]. In: VII International PeachSymposium (ISHS), Lleida, Spain 2010.

35. Cantín CM, Crisosto $\mathrm{CH}$, Ogundiwin EA, Gradziel T, Torrents J, Moreno MA, Gogorcena Y: Chilling injury susceptibility in an intra-specific peach [Prunus persica (L.) Batsch] progeny. Postharvest Biol TeC 2010, 58:79-87. | Article

36. Ogundiwin EA, Peace CP, Dandekar AM, Bliss FA, Gradziel TM, Crisosto CH: Molecular Genetic Dissection of Chilling Injury in Peach Fruit. Acta Hortic 2007, 738:633-638. | Article

37. Peace CP, Ahmad R, Gradziel TM, Dandekar AM, Crisosto CH: The Use of Molecular Genetics to Improve Peach and Nectarine Post-Storage Quality. Acta Hortic 2005, 682:403-410. | Article

38. Peace CP, Crisosto CH, Garner DT, Dandekar AM, Gradziel TM, Bliss FA: Genetic Control of Internal Breakdown in Peach. Acta Hortic 2006, 713:489-496. | Article

39. Ghiani A, Onelli E, Aina R, Cocucci M, Citterio S: A comparative study of melting and non-melting flesh peach cultivars reveals that during fruit ripening endo-polygalacturonase (endo-PG) is mainly involved in pericarp textural changes, not in firmness reduction. J Exp Bot 2011, 62:4043-4054. | Article | PubMed 